\title{
PENINGKATAN MANAJEMEN RUMAH BACA MELALUI APLIKASI SLIMS 8 DI MASJID AR-RIDLO DESA BELUNG KECAMATAN PONCOKUSUMO KABUPATEN MALANG
}

\author{
Wiwis Sasmitaninghidayah ${ }^{1}$, Muthmainnah ${ }^{2}$, Ainatul Mardhiyah ${ }^{3}$ \\ 1,2 Jurusan Fisika, UIN Maulana Malik Ibrahim Malang \\ 3Jurusan Teknik Informatika, UIN Maulana Malik Ibrahim Malang \\ Wiwishidayah87@gmail.com,muthmainnahmsi@gmail.com,ainadimana@gmail.com
}

\begin{tabular}{l} 
Info Artikel \\
\hline Riwayat Artikel: \\
Diterima: Oktober 2019 \\
Direvisi: Januari 2020 \\
Diterbitkan: Maret 2020
\end{tabular}

\section{Keywords:}

Reading House

Library Management System

Poncokusumo

\begin{abstract}
Improved management of reading houses in the Ar-Ridlo Mosque, Belung Village, Poncokusumo, Malang District. The application used is SLIMS 8. The Senayan Library Management System (SLiMS) is an open source library management system (library management system) licensed under GPL v3. The steps we have taken are making a cataloging module, making a tracking module, creating a circulation module, making a membership management module, making a collection inventory module, making a series of serial management modules and a workshop on reading house management based on Slims 8. A management workshop has been conducted with material install programs, carry out an inventory of books, register members, save and borrow activities, member card printing and book numbers.
\end{abstract}

Copyright $@ 2020 J R C E$. All rights reserved.

\author{
Korespondensi: \\ muthmainnah, \\ UIN Maulana Malik Ibrahim Malang, \\ Jl. Gajayana No. 50 Malang, Jawa Timur, Indonesia 65144 \\ muthmainnahmsi@gmail.com
}

\section{PENDAhuluan}

Kecamatan Poncokusumo merupakan kecamatan yang masuk dalam wilayah Kabupaten Malang. Kecamatan ini terdiri dari 17 desa, 47 Dusun, dihuni oleh 93.153 jiwa penduduk, dengan rincian 49.401 orang laki-laki dan 49.752 perempuan. Poncokusumo memiliki 46 unit TK (109 orang guru), 39 unit SD (383 orang guru), 23 unit MI (23 orang guru), 5 unit SMP (109 orang guru), 11 unit MTs (185 orang guru), 3 unit SMA dan MA (59 orang guru).

MASJID Ar-Ridho adalah salah satu masjid yang berada di Desa Belung kecamatan poncokusumo. Hasil Observasi kami, kunjungan pertama kali ke masjid Al-Ridlo belum ditemukan taman baca/perpustakaan yang bisa dimanfaatkan oleh warga sekitar masjid. Dari hasil wawancara dan penggalian informasi kepada pengurus takmir Masjid Al-Ridlo diperoleh informasi bahwa Remaja Masjid Al-Ridlo sudah memiliki angan-angan untuk mendirikan taman baca berbasis masjid dengan nama "Pena Langit". Namun, sampai kami turun ke lapangan, angan-angan ini masih sebatas wacana dan belum akan diwujudkan dalam jangka dekat. Ruangan yang akan dimanfaatkan menjadi perpustakaan merupakan ruangan bagian bawah masjid. Memiliki 2 pintu utama, dengan jendela sepanjang sisi luar ruangan. Semetara ini, ruangan itu difungsikan sebagai gudang peralatan masjid, berupa tikar, karpet, sound system, almari, dan beberapa bahan pustaka sumbangan dari kelompok KKM UIN Mengabdi pada tahun 2016. Semuanya dalam kondisi berdebu dan tidak terawat. 
Senayan Library Management System (SLiMS) adalah perangkat lunak sistem manajemen perpustakaan (library management system) dengan sumber terbuka yang dilisensikan di bawah GPL v3. Aplikasi ini pertama kali dikembangkan dan digunakan oleh Perpustakaan Kementerian Pendidikan Nasional, Pusat Informasi dan Hubungan Masyarakat, Kementerian Pendidikan Nasional. Seiring perkembangan waktu, aplikasi ini kemudian dikembangkan oleh komunitas pengguna dan penggiat SLiMS. Aplikasi SLiMS dibangun dengan menggunakan PHP, basis data MySQL, dan pengontrol versi Git. Pada tahun 2009, SLiMS mendapat penghargaan tingkat pertama dalam ajang INAICTA 2009 untuk kategori open source.

Kondisi yang diharapkan setelah berdirinya taman baca berbasis masjid yang terletak di masjid AlRidlo ini adalah masyarakat sekitar masjid lebih tertarik mengalihkan waktu luang mereka dengan mengunjungi masjid. Desain rumah baca yang berkonsep home library dengan aplikasi SLIMS 8 diharapkan dapat menambah kenyamanan pengguna taman baca. Variasi buku bacaan juga sudah melingkupi kebutuhan bacaan anak-anak, permainan sederhana, buku tentang parenting, wirausaha, buku-buku ensiklopedia tentang alam dan pengetahuan lain, juga buku-buku bertema bebas yang bias dinikmati semua umur. Dengan memberikan sumbangan berupa bahan literasi yang memadai diharapkan taman baca ini memiliki potensi beroperasi dalam jangka waktu lama dan memberikan manfaat kepada masyarakat sekitar, baik anak-anak, orang tua maupun remaja.

\section{METODE PENELITIAN}

Tempat Pengabdian adalah Rumah Baca di Masjid Ar-Ridlo Desa Belung Kecamatan Poncokusumo Kabupaten Malang. Aplikasi yang diguanakan untuk meningkatkan pelayanan rumah baca adalah program perpustakaan Slims 8.

Adapun langkah-langkah yang kami lakukan adalah:

a. Membuat Cataloging module

b. Membuat Modul penelusuran

c. Membuat Modul sirkulasi

d. Membuat Manajemen modul keanggotaan

e. Membuat Modul Inventarisasi koleksi

f. Workshop Manajemen Rumah Baca berbasis Slims 8

\section{HASIL DAN PEMBAHASAN}

langkah-langkah yang diterapkan dalam pembuatan aplikasi rumah baca di Masjid Ar-Ridlo Desa Belung Kecamatan Poncokusumo Kabupaten Malang adalah sebagai berikut:

a. Membuat Cataloging module

Fitur untuk membuat, mengedit, dan menghapus data bibliografi sesuai dengan standar deskripsi biliografi. Mendukung pengelolaan koleksi dalam berbagai macam format seperti monograph, terbitan berseri, audio visual, dsb. Mendukung penyimpanan data bibliografi dari situs di Internet. Mendukung penggunaan Barcode. Manajemen item koleksi untuk dokumen dengan banyak kopi dan format yang berbeda. Pengelolaan koleksi yang hilang, dalam perbaikan, dan rusak serta pencatatan statusnya untuk dilakukan pergantian/perbaikan terhadap koleksi.

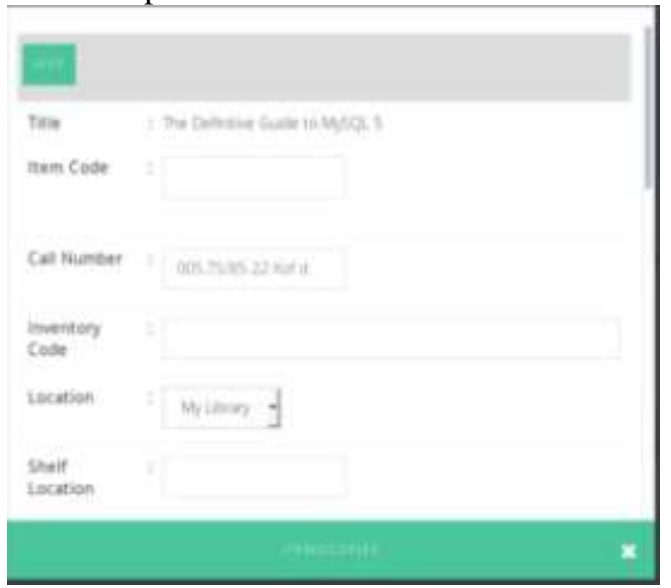

Gambar 3.1 Cataloging Module dalam Aplikasi Slims 8 
b. Membuat Modul penelusuran

Mendukung akses OPAC melalui peralatan portabel (mobile device). Menampilkan informasi lengkap tetang status koleksi di perpustakaan, tanggal pengembalian, dan pemesanan item/koleksi. Juga tersedia detil informasi juga menampilkan gambar sampul buku, lampiran dalam format elektronik yang tersedia (jika ada) serta fasilitas menampilkan koleksi audio dan visual. Menyediakan hyperlink tambahan untuk pencarian lanjutan berdasarkan penulis, dan subjek.

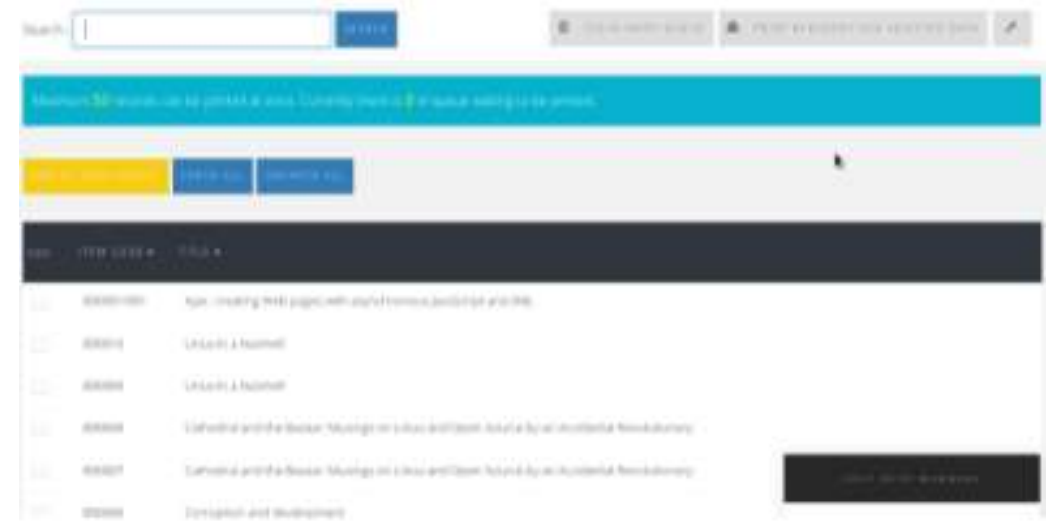

Gambar 3.2 Modul penelusuran dalam Aplikasi Slims 8

c. Membuat Modul sirkulasi

Mampu memproses peminjaman dan pengembalian koleksi secara efisien, efektif, dan aman. Mendukung fitur reservasi koleksi yang sedang dipinjam, termasuk reminder/pemberitahuan-nya. Mendukung fitur manajemen denda. Dilengkapi fleksibilitas untuk pemakai membayar denda secara cicilan. Mendukung fitur reminder untuk berbagai keperluan seperti melakukan black list terhadap pemakai yang bermasalah atau habis keanggotaannya. Mendukung fitur pengkalenderan (calendaring) untuk diintegrasikan dengan penghitungan masa peminjaman, denda, dan lain-lain. Memungkinkan penentuan hari-hari libur non-standar yang spesifik. Dukungan terhadap ragam jenis tipe pemakai dengan masa pinjam beragam untuk berbagai jenis keanggotaan. Menyimpan histori peminjaman anggota. Mendukung pembuatan peraturan peminjaman yang sangat rinci dengan mengkombinasikan parameter keanggotaan, jenis koleksi, dan gmd selain aturan peminjaman standar berdasarkan jenis keanggotaan.

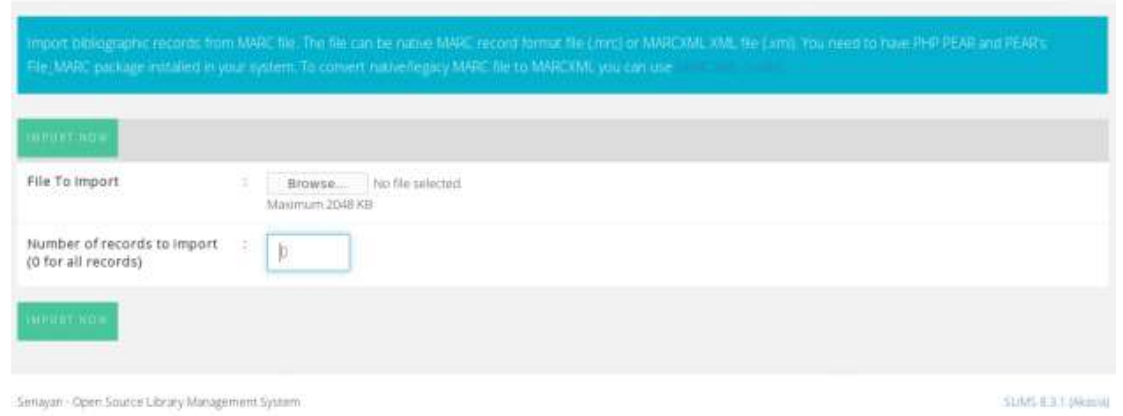

Gambar 3.3 Modul Sirkulasi dalam Aplikasi Slims 8

d. Membuat Manajemen modul keanggotaan

Memungkinkan beragam tipe pemakai dengan ragam jenis kategori peminjaman, ragam jenis keanggotaan dan pembedaan setiap layanan sirkulasi dalam jumlah koleksi serta lama peminjaman untuk jenis koleksi untuk setiap jenis/kategori. Dukungan terhadap input menggunakan barcode reader. Memungkinkan untuk menyimpan informasi preferensi pemakai atau subject interest. Memungkinkan untuk menyimpan informasi tambahan untuk keperluan reminder pada saat transaksi. Memungkinkan menyimpan informasi detail pemakai yang lebih lengkap. Pencarian informasi anggota minimal berdasarkan nomor dan nama anggota. Pembuatan kartu anggota yang dilengkapi dengan barcode untuk transaksi peminjaman 


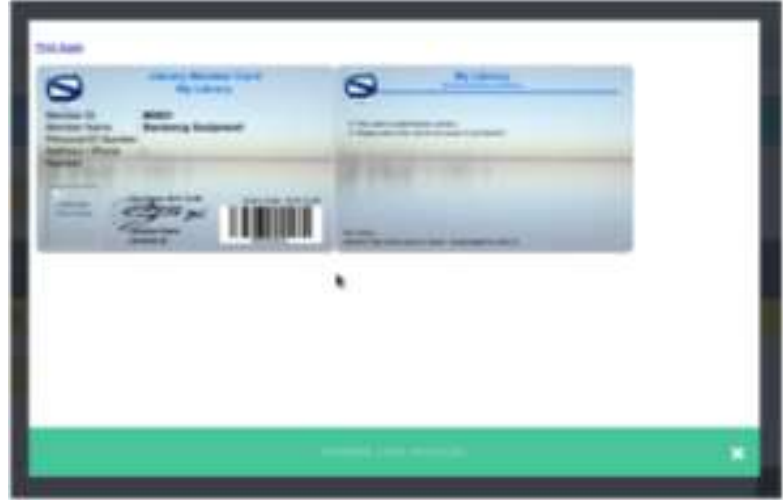

Gambar 3.4 Pembuatan Kartu Keanggotaan dalam Aplikasi Slims 8

e. Membuat Modul Inventarisasi koleksi

Meliputi pelaporan untuk semua modul-modul yang tersedia di Senayan, diantaranya:

- Laporan Judul.

- Laporan Items/Kopi koleksi.

- Laporan Keanggotaan.

- Laporan jumlah koleksi berdasarkan klasifikasi.

- Laporan Keterlambatan.

- Berbagai macam statistik seperti statistik koleksi, peminjaman, keanggotaan, keterpakaian koleksi.

- Tampilan laporan yang sudah didesain printer-friendly, sehingga memudahkan untuk dicetak.

- Filter data yang lengkap untuk setiap laporan.

- API untuk pelaporan yang relatif mudah dipelajari untuk membuat custom report baru.

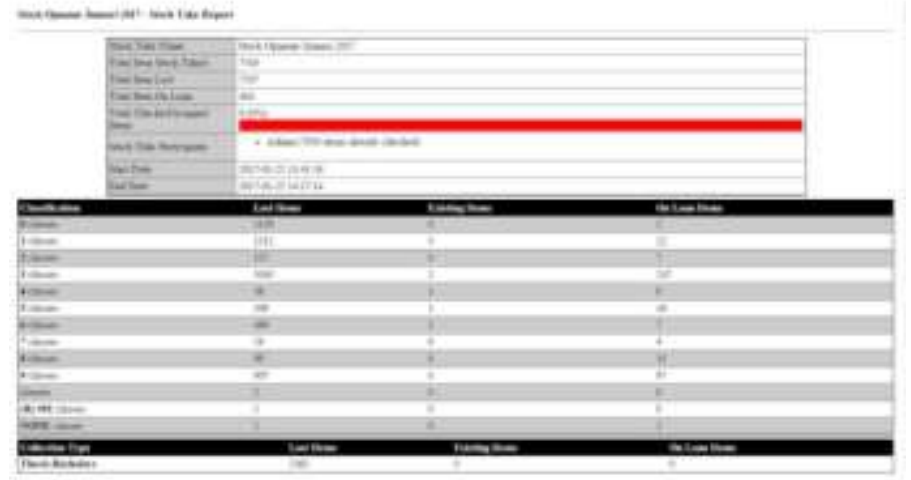

Gambar 3.5 Modul inventarisasi Koleksi dalam Aplikasi Slims 8

f. Workshop Manajemen Rumah Baca berbasis Slims 8

Workshop ini dilakukan untuk mendampingi Remaja Masjid Al-Ridlo dalam pembentukan taman baca. Kegiatan yang dilakukan adalah melakukan pemilahan bahan literasi, menyampul, menyeleksi, mengelompokkan dan menempatkan pada rak buku yang tersedia. Praktek pengelolaan taman baca dengan menggunakan program slims 8 dimulai dengan menginstal, melakukan inventaris buku, mendaftar anggota, kegiatan simpan pinjam, pencetakan kartu anggota dan nomor buku. 


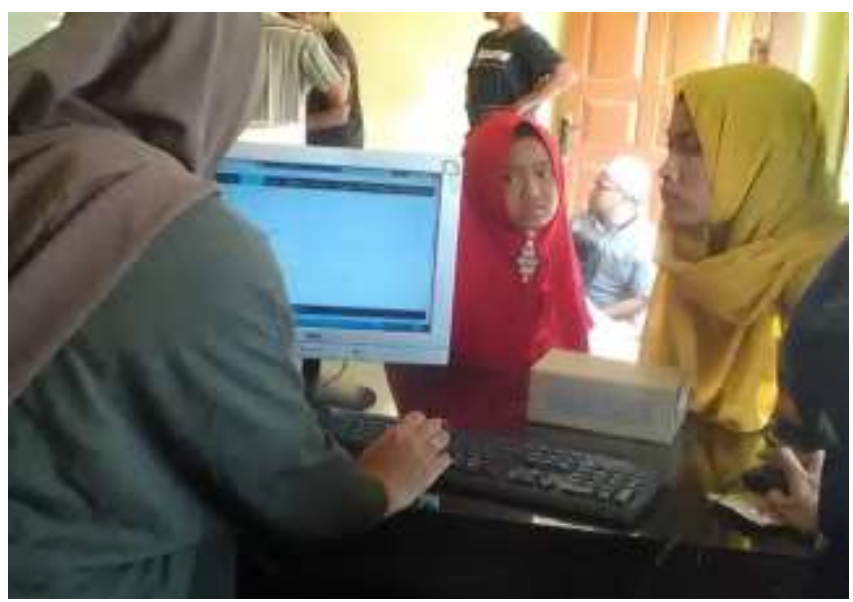

Gambar 3.6 Workshop manajemen rumah baca

\section{KESIMPULAN}

Telah dilakukan peningkatan pelayanan rumah baca di masjid Ar-Ridho menggunakan aplikasi Slims 8 melalui pembuatan Cataloging module, pembuatan Modul penelusuran, pembuatan Modul sirkulasi, pembuatan Manajemen modul keanggotaan, pembuatan Modul Inventarisasi koleksi, dan workshop Manajemen Rumah Baca berbasis Slims 8.

\section{UCAPAN TERIMAKASIH}

Sampaikan ucapan terimakasih anda kepada LP2M UIN Maulana Malik Ibrahim Malang, pengurus masjid Ar-Ridho dan adik-adik remaja masjid Ar-Ridho yang telah membantu dalam kegiatan pengabdian ini

\section{DAFTAR PUSTAKA}

Arifin, Ridwan Nur. 2012. Perpustakaan dan TBM, Versus or Featuring. Yogjakarta (diakses pada web http://coretanridwan.blogspot.com).

Budaya dan Penciptaan Lingkungan Ramah Anak, Disampaikan pada diskusi Ilmiah dalam rangka Kongres Internasionalbahasa dan adat Gorontalo I \& Hardiknas, Selasa 13 Mei 2008.

M. Rasyid Ridho. Panduan Penggunaan Aplikasi Software SENAYAN. Ebook

Putri, Gustia Windy. 2013. Rancangan Pembuatan Sarana Promosi di Taman Bacaan Masyarakat Suka Maju Sejahtera Padang. Padang: UNP (Universitas Negeri Padang)

Rifa zein. 2014. Taman Bacaan Masyarakat. (diakses pada http://rifazien.wordpress.com/2014/09/25/tamanbacaan-masyarakat/) 